\title{
A Typical Day in the Family Medicine Office
}

Clinical medicine and prevention in primary care practice are the themes of this issue, wherein we present new research with practical information on common subjects: cardiovascular outcomes with specific medications, vitamin D, calcium supplements, vaginitis, smoking, stroke and allergies, headaches and depression, hepatitis C, skin infections, general prevention examinations, sore throat, laboratory results notification, and patient medication lists. Looks like a typical day in the family medicine office! Although most of the authors are from university family medicine departments and residency programs, ${ }^{1-10}$ we also welcome contributions with implications for primary care from others outside the field. ${ }^{11-13}$

We have 2 evidence-based clinical review articles. Ong ${ }^{11}$ examined many randomized trials and has determined that angiontensin-converting enzyme inhibitors and angiotensin receptor blockers are not uniquely able to improve cardiovascular outcomes over and beyond their effects on blood pressure. This is important. One of the major bad outcomes that we try to prevent by controlling blood pressure is cardiovascular disease. In choosing among medicines for blood pressure control, we often consider their other known effects and the other risks patients may have. This review suggests that drugs from either category should not be selected solely based on potential excess benefit on cardiovascular disease, but if they are otherwise a good option and actually do control the blood pressure well.

Kulie et $\mathrm{al}^{1}$ reviewed the current literature about vitamin $\mathbf{D}$. These reviews are time consuming, and we appreciate the authors' efforts. I recently read in a lay newspaper that maybe, finally, we will find that some vitamin (ie, vitamin D) is worth taking regularly to prevent disease. Folate, of course, already fits that category for many; calcium, though not a vitamin, is a similar supplement, with evidence to support its use. However, it is often easier to detect what blood levels lead to obvious nutritional deficiency syndromes than to determine the

Conflict of interest: The authors are editors of the $7 A B F M$. ideal blood levels to prevent some entity that might be many years off and be impacted only by subtle deficiencies over a long time. We certainly still have much to learn about vitamins. This review provides up-to-date information in several categories and reminds us that actual randomized controlled trials of efficacy of supplementation for vitamin $\mathrm{D}$ are few. In the meantime, I (MAB) have been checking vitamin $\mathrm{D}$ in a number of my patients, such as those with rheumatoid arthritis or those taking long-term steroids, or sometimes that patient with idiopathic chronic muscle aches, and finding that most everyone tested has had low levels. Some patients have reported symptomatic response to supplementation and some have not. I also routinely recommend that calcium supplementation be accompanied by vitamin D supplementation.

Turning to original research reports, Matheson et $\mathrm{al}^{2}$ extend their previous work ${ }^{14}$ on the association between stroke and allergic respiratory conditions. We do not think that most physicians or patients have thought there would be such an association. This data builds on previous work by showing that actual positive allergy tests, not just reported allergic conditions, are associated with stroke. The authors present an excellent discussion of potential explanations for this finding. As yet, we do not know what we should do about this potential association.

Calcium creates confusion among patients. Many accept they should take calcium supplements, yet they worry: Why are we giving them calcium channel blockers when they are taking calcium? Does one negate the other? Having calcium in your coronaries is associated with higher rates of heart disease, so patients and their physicians sometimes wonder what we do know about the impact of calcium supplements. Bhatka et $\mathrm{al}^{12}$ look at the progression of calcium scores in coronary arteries or aortic valves in women taking calcium supplements and thankfully find no relationship.

Practical information about common problems are addressed in 2 randomized trials completed by our university family medicine colleagues. Anderson et $\mathrm{al}^{4}$ find that historic information may be as 
good as doing wet preparation when determining the treatment for vaginitis, a thorny and timeconsuming (in the case of the wet preparation) issue in our offices. More data from larger populations are needed, but this is a good start. In another interventional study using an electronic medical record, McCullough et $\mathrm{al}^{3}$ found that adding prompts for 2 questions related to smoking was associated with increased documentation of provider counseling for smoking. A next step will be demonstrating that such prompts actually lead to decreased smoking.

Marlowe et $\mathrm{al}^{7}$ find that presentation for headache in a family physician office is associated with depression. I (MAB) have always thought that patients presenting with head, abdominal, or back pain and no trauma have high rates of depression. The practical implication is that we should inquire about depression-not just with 1 or 2 questions, but with some probing.

National recommendations for a variety of diseases are conflicting across various recommending authorities, and family physician offices are where the rubber meets the road-what is actually done? Family physicians do not seem to shy away in these circumstances, and for hepatitis $\mathbf{C}$, Leverence et $\mathrm{al}^{5}$ took into account their knowledge of the patient and the medications, as well as the recommendations to deal with this problem in their patientcentered clinical practice. Patient factors are often paramount but are commonly neglected or not well addressed in these national recommendations.

Crawford et $\mathrm{al}^{13}$ provides evidence that purulence is key with skin infections; purulence suggests susceptibility to clindamycin in skin infections at a much higher rate than those infections without purulence. Grover et $\mathrm{al}^{8}$ found high rates of screening and treatment for osteoporosis among older women who received a general preventive examination compared with those who did not. More evidence supporting the recommendation of a routine physical is needed to encourage completion of needed prevention items.

Tiemstra and Miranda ${ }^{6}$ found that non-group A streptococcal (GAS) infections were associated with sore throat, fever, and headaches, similar to GAS infections. Non-GAS infections also had more lymphadenopathy and exudates than those culture negative (presumed viral). We treat GAS not just for symptoms but for prevention of later complications of the infection, specifically rheumatic fever.
Because this would not apply to non-GAS infections, we need more data on the outcomes of treating non-GAS pharyngeal infections.

In our ongoing series of information helpful to the family physician office as a medical home, we have articles about notification of laboratory test results and patient medication lists. Grimes et $\mathrm{al}^{9}$ note that patients want to be notified about their laboratory test results; patients most commonly prefer a letter for notification of normal results and a telephone call from their physician for notification of abnormal results. Satisfaction with their current physician was associated with satisfaction of current method of notification. However, there was substantial variation in preferences; asking the patient which method is preferred could help but will be insufficient for all circumstances. Chae et $\mathrm{al}^{10}$ found that a medication card list given to patients was used by a minority, but those patients then felt more personal responsibility for their medications.

Yes, it is just another day in a family medicine office, but every day-every visit-is designed to prevent some type of negative outcome, whether physical, emotional, or financial. We hope the articles in this issue of the fournal of the American Board of Family Medicine make your office visits more effective and more rewarding for you and your patients.

Marjorie A. Bowman, MD, MPA

Anne Victoria Neale, PhD, MPH

\section{References}

1. Kulie T, Groff A, Redmer J, Hounshell J, Schrager S. Vitamin D: an evidence-based review. J Am Board Fam Med 2009;22:698-706.

2. Matheson EM, Mainous AG, Carnemolla MA. The association between allergy skin testing, atopic respiratory conditions, and stroke mortality in middleaged and elderly adults. J Am Board Fam Med 2009; 22:604-9.

3. McCullough A, Fisher M, Goldstein AO, Kramer $\mathrm{KD}$, Ripley-Moffitt C. Smoking as a vital sign: prompts to ask and assess increase cessation counseling. J Am Board Fam Med 2009;22:625-32.

4. Anderson M, Cohrssen A, Klink K, Brahver D. Are a speculum examination and wet mount always necessary for patients with vaginal symptoms? A pilot randomized controlled trial. J Am Board Fam Med 2009;22:617-24.

5. Leverence RR, Williams RL, Pace W, et al. Context of clinical care: the case of hepatitis $\mathrm{C}$ in underserved communities-a report from the Primary Care Mul- 
tiethnic Network (PRIME Net) consortium. J Am Board Fam Med 2009;22:638-46.

6. Tiemstra J, Miranda RLF. Role of non-group A streptococci in acute pharyngitis. J Am Board Fam Med 2009;22:663-9.

7. Marlow RA, Kegowicz CL, Starkey KN. Prevalence of depression symptoms in outpatients with a complaint of headache. J Am Board Fam Med 2009;22: 633-7.

8. Grover M, Anderson M, Gupta R, et al. Increased osteoporosis screening rates associated with the provision of a preventive health examination. J Am Board Fam Med 2009;22:655-62.

9. Grimes GC, Reis MD, Budati G, Gupta M, Forjuoh SN. Patient preferences and physician practices for laboratory test results notification. J Am Board Fam Med 2009;22:670-6.

10. Chae SY, Chae MH, Isaacson N, James TS. The patient medication list: can we get patients more involved in their medical care? J Am Board Fam Med 2009;22:677-85.

11. Ong HT. Are angiotensin-converting enzyme inhibitors and angiotensin receptor blockers especially useful for cardiovascular protection? J Am Board Fam Med 2009;22:686-97.

12. Bhakta M, Bruce C, Messika-Zeitoun D, et al. Oral calcium supplements do not affect the progression of aortic valve calcification or coronary artery calcification. J Am Board Fam Med 2009;22:610-6.

13. Crawford SE, David MZ, Glikman D, King KJ, Boyle-Vavra S, Daum RS. Clinical importance of purulence in methicillin-resistant Staphylococcus aureus skin and soft tissue infections. J Am Board Fam Med 2009;22:647-54.

14. Matheson EM, Player MS, Mainous AG, King DE, Everett CJ. The association between hay fever and stroke in a cohort of middle aged and elderly adults. J Am Board Fam Med 2008;21:179-83. 